\title{
CONDITIONAL CONSTRUCTIONS IN BUWAL
}

\author{
Melanie Viljoen \\ SIL Cameroon
}

\begin{abstract}
Buwal is a Central Chadic language spoken in the Far North Region of Cameroon. This study examines the structure of conditional constructions in Buwal and their functions. Conditionals in Buwal can be divided into four major categories according to how they are marked: possible, counterfactual, necessary and concessive. Possible conditionals include both reality and unreality conditionals. The usual order is for the protasis to precede the apodosis, but the reverse order is also possible. All types of tense/aspect marking are possible in both the protasis and the apodosis with variations arising from semantic rather than grammatical restrictions. The possible conditional marker can also function as a temporal marker in certain contexts. In a conditional construction, the protasis provides a framework or background for the apodosis.
\end{abstract}

Keywords: conditional, Buwal, Chadic

\section{Introduction}

Buwal is a Central Chadic language spoken by approximately 10000 people in and around the village of Gadala in the Far North Region of Cameroon, Mayo-Tsanaga Division, Mokolo Subdivision. Buwal's classification according to the Ethnologue (Lewis, Simons \& Fennig 2014) is Afroasiatic, Chadic, Biu-Mandara, A, A7. The majority of linguistic research done on this language has been conducted by the author, who completed a description of the grammar to fulfil the requirements of a Ph.D. in 2013. This study, although partially based on this description, goes into greater depth than the description in examining both the structure of Buwal conditionals and their functions.

\section{Structure of Buwal Conditional Constructions}

Conditional constructions in Buwal can be divided into four major categories according to how they are marked; possible (1.1), counterfactual (1.2), necessary (1.3) and concessive (1.4). These are discussed in more detail in the subsections below. Section 1 ends with a description of conditional constructions which have more than one protasis (1.5).

1.1 Possible Conditionals. Possible conditionals are those for which it is possible for the condition to be fulfilled (Dixon 2009: 15). This category in Buwal includes Taylor's (1997) 'factual' conditionals, where the protasis is known to be true, and 'hypothetical' conditionals where the protasis could happen, but might not. The protasis is preceded by the conditional marker màd $\bar{a}$ 'if' for the vast majority of examples in the corpus, ${ }^{1}$ as exemplified in (1). In the

1 The corpus consists of ninety-nine transcribed and interlinearized texts of various genres, numerous elicited examples and a lexicon of more than three thousand items. 
interlinearized examples throughout this paper, the protasis is marked with "P" and the apodosis with "Q" on the Buwal language line. A list of abbreviations can be found at the end of the document.

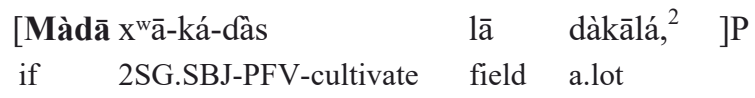

$\begin{array}{llll}{\left[\mathrm{X}^{\mathrm{w}} \overline{\mathrm{a}} \text {-ná-lèm }\right.} & \text { kàn } & \text { dàkālá } & \text { jám.]Q } \\ \text { 2SG.SBJ-FUT-get } & \text { thing } & \text { a.lot } & \text { also }\end{array}$

'If you have cultivated fields a lot, you will also get a lot of crops.'

Frajzyngier (1996: 375) notes that $m a$ is a common conditional marker in Chadic, occurring in two of the four branches. While in Buwal má is not used to mark conditional clauses, it is used a temporal marker (see section 2). The conditional marker $d a$ is also found in Hausa, Giziga and Mofu-Gudur (Frajzyngier 1996: 377; Hollingsworth 2004: 46). It is probable that the Buwal possible conditional marker màda developed from a combination of these two morphemes. There has historically been close contact between Mofu-Gudur and Buwal speakers and the two language areas currently border on each other.

Possible conditionals in Buwal include all types of reality conditionals; present (2a), habitual/generic (2b) and past (2c), from Thompson, Longacre and Hwang's (2007: 255-262) classification.

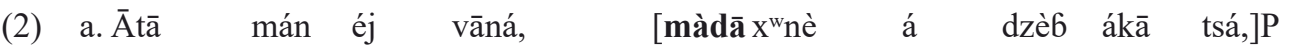
ASS.PL mother and father.3POSS if 2PL.STAT PREP $1^{3}$ tomb EXIST TOP [X $\mathrm{X}^{\mathrm{w}}$ né-sār lā á-tā $\quad$ mtàx $^{\mathrm{w}}$ nā égē. $] \mathrm{Q}$ 2PL.SBJ-look.at place PREP1-on orphan 1SG.POSS =PL

'My mother and father, if you are in the tomb, watch over my orphans.'

b. [Màdā wālā ā-dā wālā á váwātsà, $] P$ if woman 3SG.SBJ-draw woman PREP1 this.year

[j'ná-mbāl á māk ấ.]Q

3PL.SBJ-FUT-catch PREP1 next.year

'If a woman marries this year, they will capture her the next year.'

2 The tones marked here are underlying tones. Buwal has three level tones; low, mid and high.

3 The Buwal prepositions $a$ and $\dot{y}$ each carry a variety of meanings and so are glossed PREP1 and PREP2. 


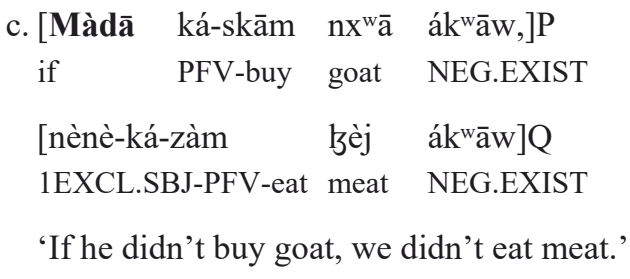

Possible conditionals also cover the hypothetical (3a) and predictive (3b) categories of unreality conditionals following Thompson, Longacre and Hwang's (2007: 255-262) classification. Counterfactual conditionals are marked differently, as discussed in section 1.2.

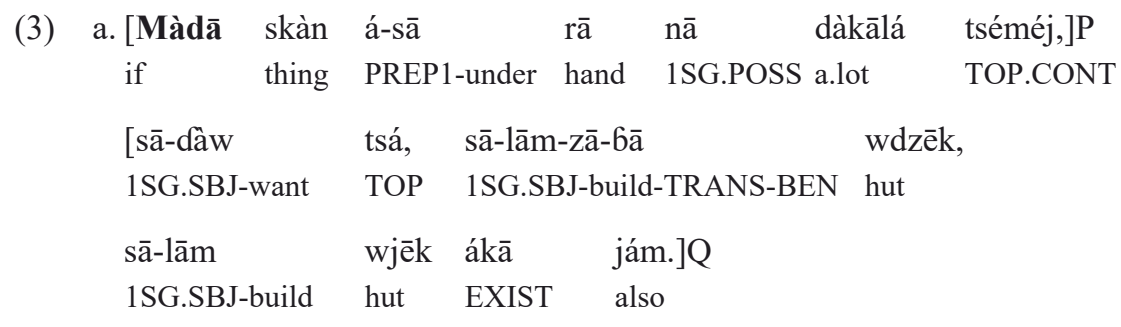

'If I had a lot of things, I (would) want to repair huts for myself, to build huts also.'
b. [Màdā sā-vāy á wātā,]P [j́ná-zàm $\quad$ wdā.]Q if 1SG.SBJ-arrive PREP1 home 3PL.SBJ-FUT-eat food
'If (when) $)^{4}$ I arrive home, they will eat food.'

Another conditional marker used with possible conditionals in Buwal is $\bar{a} n d z \bar{a}$ 'if', as in (4). It was found only in a small number of elicited examples and may have been borrowed from MofuGudur, in which language it can also be translated as 'when' (Hollingsworth 2004: 46). The only examples using this marker in the corpus were present reality conditionals. However, since the number of examples is so small, it is unknown at this stage whether this marker is restricted to this type of conditional.

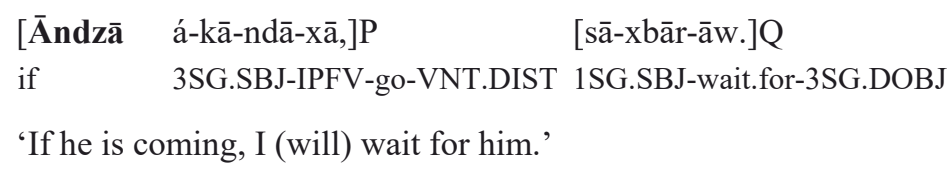

The apodosis of a conditional construction in Buwal does not take a specific marker. Examples were found in the data of four types of result clause; content (2b), epistemic (2c), directive (2a) and interrogative (6). Directive clauses may consist of either an imperative construction (2a) or a clause expressing obligation, such as one preceded by the particle séj 'except/only' (5).

4 In certain contexts the possible conditional marker màdā can be translated 'when'. This will be discussed further in section 2 . 
(5)

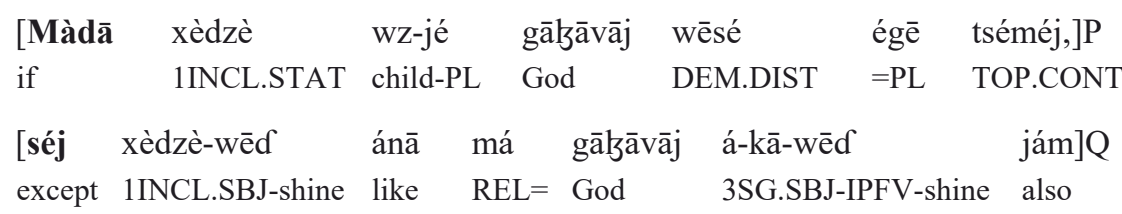

'But if we are those children of God, we must also shine like God shines.'

An interrogative apodosis is marked with a clause final question word (6)

(6)

\begin{tabular}{|c|c|c|c|c|c|}
\hline $\begin{array}{ll}\text { Káw } & \text { vájáj } \\
\text { even } & \text { who }\end{array}$ & $\begin{array}{l}\text { mā- }{ }^{w} \text { āl-zāa } \\
\text { JUS-explain-TRANS }\end{array}$ & $\begin{array}{l}\text { [màdā } \\
\text { if }\end{array}$ & $\begin{array}{l}\text { ká-ndzā } \\
\text { PFV-be }\end{array}$ & $\begin{array}{l}\text { ń bāj } \\
\text { PREP2 } \\
\text { chief }\end{array}$ & $\begin{array}{l}\text { tsá,]P } \\
\text { TOP }\end{array}$ \\
\hline [ā-ná-la- & á & xèdzè-jé & tsá & méj?]Q & \\
\hline 3SG.SBJ-FU' & -do-3PL.IOBJ & person-PI & TOP & nat & \\
\hline
\end{tabular}

'Let each one explain, if they were to become chief, what would they do for people?'

As can been seen from the examples above, Buwal does not make a formal distinction between reality and unreality type conditionals apart from counterfactual, in terms of special marking. The meaning must be determined from the context. Schuh (1972: 330) states that this is also the case for Ngizim, although Frajzyngier (1996: 373) asserts for most of the Chadic languages he examined, the unreality conditional is derived from the construction of the reality conditional plus additional morphemes.

Certain Chadic languages exhibit restrictions on TAM marking found in both the protasis and the apodosis of conditional constructions. For example in Goemai, the habitual aspect construction cannot be used in the protasis, and the apodosis is not marked for aspect but may be marked with irrealis modality (Hellwig 2011: 460-461).

Tables 1 and 2 below provide a summary of the tense and aspect marking found in the protasis and the apodosis respectively for different types of possible conditionals in Buwal. As in many Chadic languages, in Buwal, aspect is more important than tense. The aspectual system is divided between perfective, marked with the verbal prefix $k a$ - and imperfective, marked with the prefix $k \bar{a}$-. There is also a future tense prefix ná-. Verbs with no tense/aspect prefix (labelled 'Unmarked' in Tables 1 and 2), are unspecified for tense and aspect. ${ }^{5}$ Verbless clauses, where the predicate may be a noun, adjective, prepositional phrase or an existential marker, are also unmarked for tense and aspect, and have been given a separate column in Tables 1 and 2 below. Imperative clauses have been included in Table 2 as they can be found in the apodosis of a conditional construction. In both tables, an " $\mathrm{X}$ " indicates that the specified type of tense/aspect marking or clause type was found in the corpus for a particular semantic type of conditional. In each table, reality conditionals are found above the bolded line, and unreality conditionals below.

5 For a detailed description of the Buwal tense/aspect system see Viljoen (2013: 359-371). 
Table 1: Summary of tense/aspect marking in the protasis of possible conditionals

\begin{tabular}{|l|l|l|l|l|l|}
\hline Type & Verbless & Unmarked & Imperfective & Perfective & Future \\
\hline Present & $\mathrm{X}$ & $\mathrm{X}$ & $\mathrm{X}$ & - & - \\
\hline Habitual/Generic & $\mathrm{X}$ & $\mathrm{X}$ & $\mathrm{X}$ & $\mathrm{X}$ & $\mathrm{X}$ \\
\hline Past & - & - & - & $\mathrm{X}$ & - \\
\hline Hypothetical & $\mathrm{X}$ & $\mathrm{X}$ & $\mathrm{X}$ & $\mathrm{X}$ & - \\
\hline Predictive & - & $\mathrm{X}$ & $\mathrm{X}$ & $\mathrm{X}$ & $\mathrm{X}$ \\
\hline
\end{tabular}

Table 2: Summary of tense/aspect marking in the apodosis of possible conditionals

\begin{tabular}{|l|l|l|l|l|l|l|}
\hline Type & Verbless & Unmarked & Imperfective & Perfective & Future & Imperative \\
\hline Present & $\mathrm{X}$ & $\mathrm{X}$ & - & $\mathrm{X}$ & $\mathrm{X}$ & $\mathrm{X}$ \\
\hline Habitual/Generic & $\mathrm{X}$ & $\mathrm{X}$ & $\mathrm{X}$ & - & $\mathrm{X}$ & $\mathrm{X}$ \\
\hline Past & - & - & $\mathrm{X}$ & $\mathrm{X}$ & - & - \\
\hline Hypothetical & - & $\mathrm{X}$ & $\mathrm{X}$ & - & $\mathrm{X}$ & $\mathrm{X}$ \\
\hline Predictive & $\mathrm{X}$ & $\mathrm{X}$ & - & - & $\mathrm{X}$ & $\mathrm{X}$ \\
\hline
\end{tabular}

The tables above show that in Buwal, all types of tense/aspect marking are possible in both the protasis and the apodosis of a conditional construction. However, a certain amount of variation can be observed according to the semantic type. For example, only the perfective aspect occurs in the protasis of past conditionals and neither the perfective aspect nor the future tense occurs in the protasis of present conditionals. For the apodosis, the main restriction appears to be that the perfective aspect does not occur in the apodosis of an unreality conditional. Furthermore, in Buwal an apodosis may be an imperative clause. It is not possible, perhaps obviously, for the protasis to be an imperative because an imperative cannot be a condition.

The variation in tense and aspect according to the type of conditional is more likely due to restrictions arising from the semantic relationship between the events expressed by each clause, rather than reflecting a grammatical restriction. For example, the situation expressed by the apodosis is often interpreted as a result of the condition expressed by the protasis. Therefore the event expressed by the apodosis usually occurs either after or at the same time as the event expressed by the protasis. As a result, future tense marking occurs more frequently in the apodosis than the protasis $(1,2 b, 3 b, 6)$. However, it is possible for the future marker to be found in the protasis as in example (7) below where the two events are presented in reverse chronological order. In this case it is an anticipated future event (the bringing home of crops) which determines the present action of the participants (the making of a sacrifice).

\begin{tabular}{|c|c|c|c|c|c|}
\hline [Màdā & j-ná-dātā & á & & itā,]P & \\
\hline if & 3PL.SBJ-FUT-bring-3PL.I & DOBJ & REP1 & & \\
\hline [j'-lā & kª́kª̀s & āzá & ánā & èbè & mpàr.]Q \\
\hline 3PL.SBJ-do & DEF.DET & COMPL & like & DEM.MED & first \\
\hline
\end{tabular}

'If (when) they are going to bring them (the crops) home, they make the sacrifice like this first.' 
Furthermore, perfective marking occurs far more frequently in the protasis rather than the apodosis, as the perfective in Buwal indicates an event which is completed $(1,6)$. This explains its occurrence in the protasis of past conditionals. It is possible however, for the perfective to occur in the apodosis as in example (2c) where both clauses contain the perfective form of the verb, indicating that the events occurred (or did not occur in this case) around the same time in the past.

In Buwal, the protasis commonly precedes the apodosis and is optionally followed by a topic marker $^{6}$ (2a, 3a, 5 \& 6). This is the order commonly found in Chadic languages (Wolff 1983: 247; Newman 1974: 113; Lovestrand 2012: 202; Hoskinson 1983: 129; Frajzyngier 2008: 441; Frajzyngier 2001: 419; Hellwig 2011: 258). However, in Buwal the reverse order is also possible as in example (8) below. This agrees with Frajzyngier's statement that in Chadic languages in general, the protasis normally precedes the apodosis but in some instances, the order may be reversed (1996: 373).

$$
\begin{aligned}
& \text { [J́-dzā-ētēnē mbáh } \left.{ }^{\mathrm{w}}\right] \mathrm{Q} \\
& \text { 3PL.SBJ-hit-3PL.IOBJ pardon }
\end{aligned}
$$

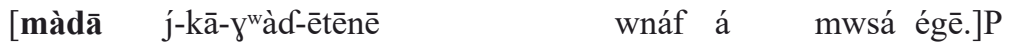

$$
\begin{aligned}
& \text { if 3PL.SBJ-IPFV-anger-3PL.IOBJ heart PREP1 twin }=\mathrm{PL}
\end{aligned}
$$

'They beg their pardon, if they anger twins.'

In Buwal both the protasis (9a) and the apodosis (9b) can be negated. In fact, although rare, it is possible for both clauses to be negated at the same time (2c). Newman (1974: 114) also found this to be the case for Kanakuru and Hellwig (2011: 461) for Goemai.

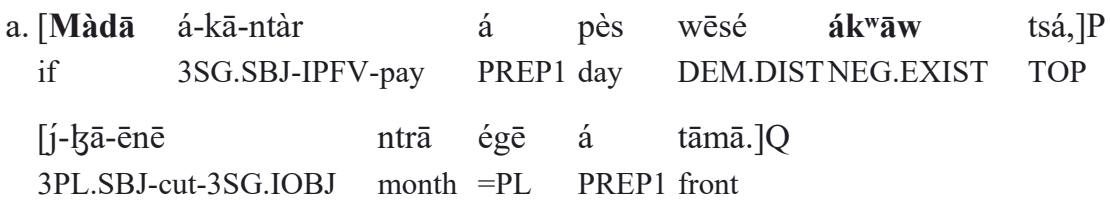

'If he doesn't pay on that day, they give him a few months in the future.'

b. [Màdā gwlàk á wātā dējdéj tséméj,]P if arguing PREP1 home too.much TOP.CONT

[xèdzè-jé tsá j-kā-ndzā $\quad$ á $\quad$ zxāj $\left.\quad \mathbf{a ́ k}^{\mathbf{w}} \mathbf{a} \mathbf{w}.\right] \mathrm{Q}$

person-PL TOP 3PL.SBJ-IPFV-live PREP1 peace NEG.EXIST

'If there is too much arguing at home, people, they do not live in peace.'

6 Many Chadic languages, particularly belonging to the Central branch, have what is commonly called a 'topic' marker. Its general function is to separate information of unequal importance; the most important, or salient information following the topic marker. For each individual language, this marker has a variety of specific syntactic and pragmatic functions. Buwal has four different topic markers. For more detail on the functions of these topic markers see Viljoen (2013: 612-621). 
1.2 Counterfactual Conditionals Counterfactual conditionals are those for which it is no longer possible for the condition to be met (Dixon 2009: 15). In other words, the protasis is known to be false. This contrasts with 'possible' conditionals in Buwal where the protasis is either known to be true or may still happen.

In Buwal, counterfactual conditionals are marked with the modal adverb kêée 'perhaps' (10). There are significantly fewer examples of these in the corpus than possible conditionals and many of these are elicited, such as example (10a). In all the examples, the protasis precedes the apodosis.

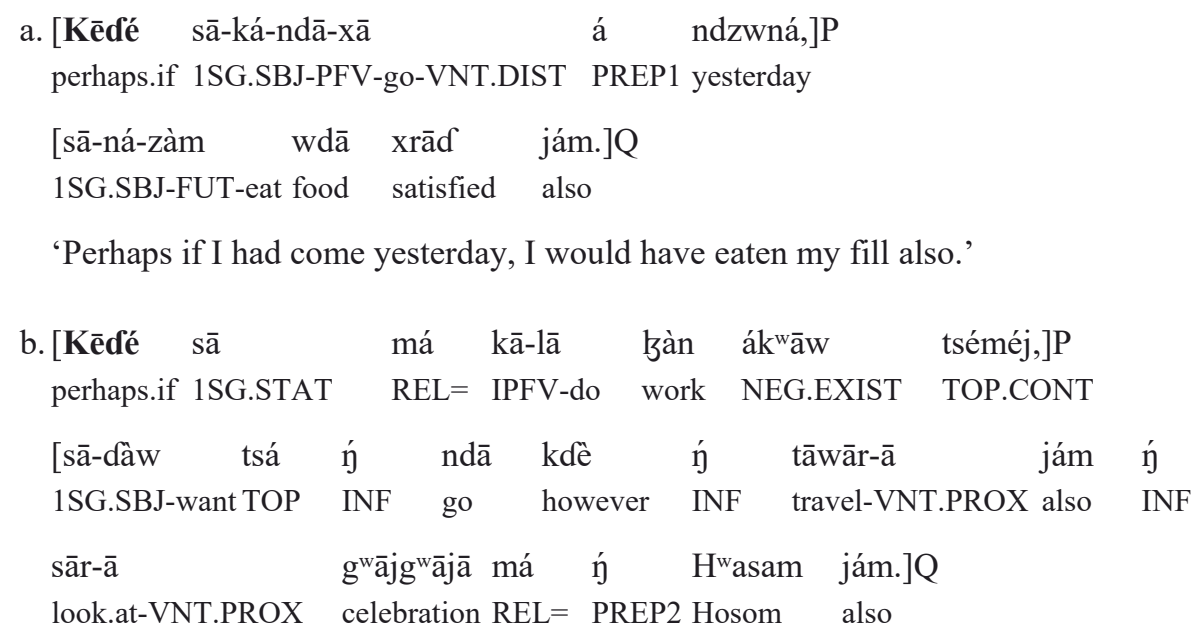

'Perhaps if I was not the one doing work, I wanted to go and travel also, to look at the celebration in Hosom also.'

A common pattern for tense/aspect marking for counterfactual conditional clauses is perfective in the protasis and future in the apodosis (10a). No examples were found of future marking in the protasis. This is not surprising as the event in the protasis would normally precede the event in the apodosis chronologically. However, examples were also found with an imperfective (10b) or an unmarked verb in the protasis as well as one example of a verbless clause (11). This example is also interesting because of the perfective marking on the verb in the apodosis. This is possible in this case because the protasis describes a state which existed both in the past and into the present. Therefore restrictions due to chronological sequence of events do not apply in this case.

(11) Wárbá $\quad \mathrm{X}^{\mathrm{w}} \overline{\mathrm{a}} \quad \mathrm{K}^{\mathrm{w} a ́ d a ̄} \mathrm{k}^{\mathrm{w}} \mathrm{a} w$, [kēdé $\quad \mathrm{k}^{\mathrm{w}} \overline{\mathrm{a}} \mathrm{w} \quad$ tsá,]P fortunately 2SG.STAT Koda NEG perhaps.if NEG.EXIST TOP

[ $\mathrm{X}^{\mathrm{w}} \overline{\mathrm{a}}-\mathrm{ká}-\mathrm{dza} \mathrm{a} \quad$ mātsāx $\left.{ }^{\mathrm{w}} \quad \overline{\mathrm{a}} \mathrm{zá}.\right] \mathrm{Q}$

2SG.SBJ-PFV-kill mother.2POSS COMPL

'Fortunately you are not Koda, ${ }^{7}$ perhaps if it was otherwise, you would have killed your mother.'

7 Koda is the name given to the eighth-born child. This child is considered to be dangerous. 
1.3 Necessary Conditionals. A necessary condition is one which must obligatorily be fulfilled if the result is to take place. In Buwal a necessary conditional is marked with the particle séj 'except/only' preceding the protasis (12). This particle has already been seen in example (5) where it was used to indicate obligation in the apodosis. It may well have been borrowed from Fulfulde (Noye 1974: $233 \&$ 341), the trade language of the area, but a similar particle is also used to mark necessary conditionals in other Chadic languages such as Margi (Hoffman 1963: 284) and Goemai (Hellwig 2011: 462). In the case of Goemai, Hellwig states that this particle is borrowed from Hausa.

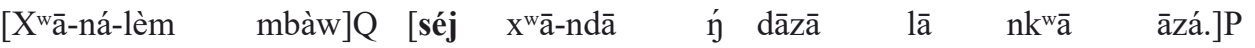

$$
\begin{aligned}
& \text { 2SG.SBJ-FUT-get child only.if 2SG.SBJ-go INFdo.sacrifice place 2SG.POSS COMPL }
\end{aligned}
$$

Out of the five examples of necessary conditionals in the corpus, three have the order of apodosis followed by protasis which is the opposite of the normal order found with possible and counterfactual conditionals described above. Two examples were found with the protasis followed by the apodosis. In each case there is some special marking preceding the apodosis emphasizing its consequential nature, such as the sequential marker āmbá in (13a) and the disjunctive marking consisting of a negative marker followed by a topic marker in (13b).
a. [Séj j-mā-mbāl nxèl āzá,]P only.if 3PL.SBJ-JUS-catchthief
COMPL
[āmbá j-ná-lā
g'mā āntā.]Q

\begin{tabular}{|c|c|c|c|c|c|c|}
\hline $\begin{array}{r}\text { b. [Séj ā-tsā- } \\
\text { only.if } 3 \text { SG.S }\end{array}$ & $\begin{array}{ll}\text { ā } & \text { sásábāj } \\
\text { BJ-put-BEN bark }\end{array}$ & $\begin{array}{l}\text { mālā } \\
\text { GEN }\end{array}$ & $\begin{array}{l}\text { mpè } \\
\text { tree }\end{array}$ & $\begin{array}{l}\text { égē,]P } \\
=\mathrm{PL}\end{array}$ & & \\
\hline $\begin{array}{l}{\left[\mathbf{a ́ k}^{\mathbf{w}} \mathbf{a} \mathbf{w}\right.} \\
\text { NEG.EXIST }\end{array}$ & $\begin{array}{ll}\text { tsá, } & \text { j' } \\
\text { TOP } & \text { 3PL.STAT }\end{array}$ & $\begin{array}{l}\text { gwlá } \\
\text { able }\end{array}$ & $\begin{array}{l}\text { ý } \\
\text { INF }\end{array}$ & $\begin{array}{l}\text { lā-ēnē } \\
\text { do-3SG.IOBJ }\end{array}$ & $\begin{array}{l}\text { nté } \\
\text { shoe }\end{array}$ & $\begin{array}{l}\left.\text { sk }^{\mathrm{w}} \bar{a} w .\right] \mathrm{Q} \\
\mathrm{NEG}\end{array}$ \\
\hline
\end{tabular}

'Only if they catch the thief first, then they will do the judgement.'

'Only if he put on the bark of trees, otherwise they were not able to make him shoes."

1.4 Concessive Conditionals. For concessive conditionals, the situation in the apodosis holds true whether or not the condition in the protasis is fulfilled. Such conditionals in Buwal are marked with the particle káw 'even' preceding the protasis, as in (14). This marker is commonly found in Chadic languages and in the case of Buwal may have been borrowed either from Fulfulde (Noye 1974: 332) or Hausa koo (Wolff 1983: 249). There is an idea of counter-expectation here as there is an assumption that if the condition holds, it should preclude the resulting situation. For example in (14) below, it is somewhat surprising that an old man should still be taking a wife.

\footnotetext{
8 In this case it is assumed that the woman has offended the spirit of a particular place which is preventing her from conceiving and therefore needs to be appeased.

9 This comes from the story of a giant named Vezpembem who was so large he could not wear ordinary shoes.
} 


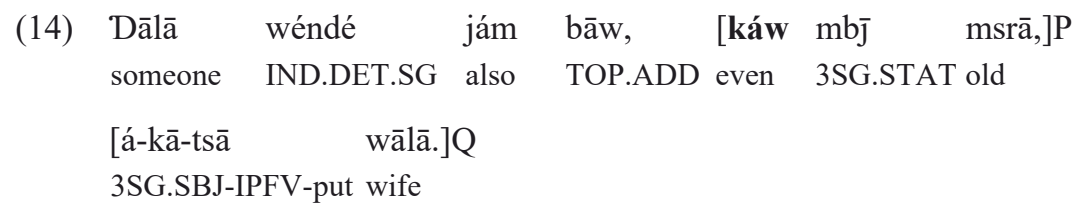

'Someone else, even if he is old, he takes a wife.'

While concessive conditionals may not be considered true conditionals, they have been included here for several reasons. Firstly, their structure is very similar to possible conditionals. The protasis precedes the apodosis and may optionally end with a topic marker. Both the protasis and the apodosis may be negated. The same variety of tense/aspect marking can be observed for each clause as for possible conditionals. Secondly, in terms of special marking, two examples were found in a natural text where the protasis was preceded by both káw 'even' and the possible conditional marker màdā 'if' (15).

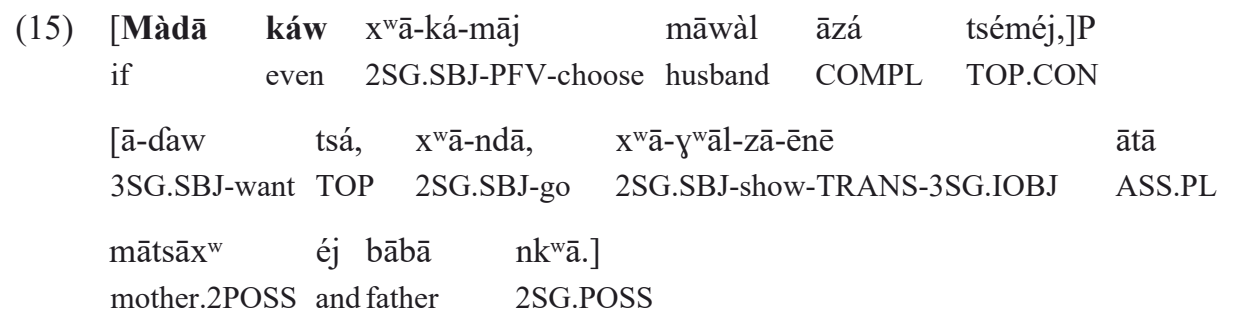

'Even if you have already chosen a husband, you (should) go and show him to your mother and father.'

Finally, the meaning of concessive conditionals in Buwal appears very close at times to ordinary possible habitual/generic conditionals. This is particularly the case when illustrative examples are being given. The two sentences in (16) below are taken from a text where the speaker gives examples of what good friends do for each other. For these examples there appears to be very little implied contrast.

\begin{tabular}{|c|c|c|c|c|c|}
\hline a. [Káw & $\begin{array}{l}X^{w} \bar{a}-g r e \bar{e} \\
2 S G \text { SBI-see }\end{array}$ & skàn & ygámà $n k^{w} \bar{a}$ & á-kā-gāj & $\begin{array}{l}\text { āntā,]P } \\
\text { 3SG.POSS }\end{array}$ \\
\hline$\left[\mathrm{x}^{\mathrm{w}} \overline{\mathrm{a}}-1\right.$ & $x^{w} \bar{a}-1$ & n-zā & ká.]Q & & \\
\hline 2SG.SI & BJ-go & BJ-build-TRANS & ANT & & \\
\hline
\end{tabular}

'If you see for example, something of your friend's is deteriorating, you go and fix it.'

$\begin{array}{llllll}\text { b. [Káw ánā } & \text { skàn } & \text { āntā } \quad \text { ánā } & n x^{w} \bar{a} & \text { anntā, á-kā-dèdèr } \\ \text { even like } & \text { thing } & \text { 3SG.POSS like } & \text { goat } & \text { 3SG.POSS } & \text { 3SG.SBJ-IMPV-wander }\end{array}$ á dámāw, $] \mathrm{P}\left[\mathrm{X}^{\mathrm{w}} \overline{\mathrm{a}}-\mathrm{nda}, \quad \mathrm{x}^{\mathrm{w} a \overline{-}}-\mathrm{tāk}-\bar{e} n \bar{e} \quad\right.$ ká.]Q

PREP1 bush 2SG.SBJ-go 2SG.SBJ-obstruct-3SG.IOBJ ANT

'If for example, his animal like his goat is wandering in the bush, you go and prevent it (from wandering) for him.' 
1.5 Conditionals With More Than One Protasis. It is possible for a conditional construction to have more than one protasis. Each protasis may be marked with a conditional marker, as shown in (17).

\begin{tabular}{|c|c|c|c|c|c|c|c|}
\hline $\begin{array}{l}\text { [Màdā } \\
\text { if }\end{array}$ & $\begin{array}{l}\text { j-dzā } \\
\text { 3PL.SBJ-hit }\end{array}$ & $\begin{array}{l}\text { Nmá } \\
\text { dgment }\end{array}$ & $\begin{array}{ll}\text { āntā } & \text { nà } \\
\text { 3SG.POSS now }\end{array}$ & $\begin{array}{l}\text { nyē,]P1 } \\
\text { DEM.PR }\end{array}$ & & & \\
\hline [màdā & āntā & tsá,]P2 & [j'-bā-ēnē & & vā & ท́ & wdzēk \\
\hline if & 3SG.POSS & S TOP & 3PL.SBJ-cut- & SG.IOBJ & year & PREP2 & house \\
\hline $\begin{array}{l}\text { jgàz, lén } \\
\text { punish plu }\end{array}$ & $\begin{array}{ll}\text { slāj má } & \text { money } \\
\text { REL }=\end{array}$ & $\begin{aligned} & \text { á-tā } \\
= & \text { PREP1- }\end{aligned}$ & $\begin{array}{l}\text { ntàr.]Q } \\
\text { on pay }\end{array}$ & & & & \\
\hline
\end{tabular}

'If they do his judgement now, if he is found guilty, they give him years in prison plus a fine.'

In Goemai, Hellwig (2011: 459) found that the conditional particle must mark each clause if they are coordinated. However, in Buwal, it is not obligatory that each protasis be marked with a conditional marker as in the following example (18), which has four protasis clauses, the first two of which are marked and the second two of which are not.

(18) [Màdā ká-lèm slāj āntā á pès má á-tā dzā if PF-get money DEF.DET PREP1 day REL= PREP1-on hit

gwāā āntā ák âāw,]P1 [màdāwjēk xèjè āntā ákā,]P2

judgement DEF.DET NEG.EXIST if house person DEF.DET EXIST

[j-kā-sàn bāj āntā,]P3 [j-kā-sàn $\quad$ lā-njá āntā tsá,]P4

3PL.SBJ-IPFV-know chief 3SG.POSS 3PL.SBJ-IPFV-know place-live 3SG.POSS TOP

[j-bzā-ēnē wān má á-tā ntàr slāj āntā.]Q

3SG.SBJ-cut-3SG.IOBJ day REL= PREP1-on pay money 3SG.POSS

'If he hasn't got the money on the day of the judgement, if the person has a house, (if) they know his chief, (if) they know where he lives, they give him days in which to pay the money.'

Different types of conditionals may occur in the same sentence. Example (19) below contains both possible and concessive conditional clauses. 
(19) [Màdā xèdzé-kā-njèn tàf á xēđé á xēđé tséméy,]P1 if $\quad$ IINCL.SBJ-IPFV-follow path PREP1 on.that PREP1 on.that TOP.CONT

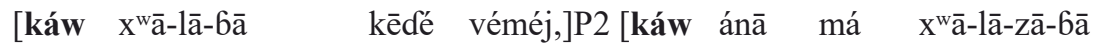
even 2SG.SBJ-do-BEN perhapswhat even like REL= 2SG.SBJ-do-TRANS-BEN

k $\mathrm{k}^{\mathrm{w} e ́ s e ̄} \quad \mathrm{nk}^{\mathrm{w}} \overline{\mathrm{a}} \quad$ á lẃmà,]P3 [gājāāāj má tsàk-zā-āxwāw.]Q doughnut 3SG.POSS PREP1 market God REL= help-TRANS-2SG.IOBJ

'If we follow the path properly, whatever you may be doing, even if for example you make doughnuts at the market, God is the one who helps you.'

In example (20) below, a necessary conditional is embedded in the apodosis of a possible conditional.

\begin{tabular}{|c|c|c|c|c|c|c|}
\hline $\begin{array}{l}{[\text { Màdāa }} \\
\text { if }\end{array}$ & $\begin{array}{l}\text { wēlbē } \\
\text { spirit }\end{array}$ & $\begin{array}{l}\text { āntā } \\
\text { DEF.DET }\end{array}$ & $\begin{array}{l}\text { ká-mbāl-zā,]P1 } \\
\text { PFV-take.hold }\end{array}$ & $\begin{array}{l}\text { [[wéndé } \\
\text { IND.DET.SG }\end{array}$ & $\begin{array}{l}\text { ā-ná-lèm } \\
\text { 3SG-FUT-get }\end{array}$ & $\begin{array}{l}\text { mbàw,]Q2 } \\
\text { child }\end{array}$ \\
\hline [séj & ā-ndā & ý & -zā $\quad$ lā & wēsé & āzá.]P2]Q1 & \\
\hline only.if & 3SG-go & INF & ke.sacrifice place & DEM.DIST & COMPL & \\
\hline
\end{tabular}

'If the spirit has taken hold of her, a certain one will have a child only if she goes to make a sacrifice to that place first.'

\section{Isomorphy of Possible Conditional Marker}

In a number of Chadic languages, the same marker is used for both conditional and temporal clauses (Frajzyngier 1996: 376; Hoskinson 1983: 129; Hoffman 1963: 283-284; Hellwig 2011: 457; Lovestrand 2012: 202). In Buwal, temporal clauses are often marked with má which is identical to the relative marker (21) and which is never used for conditional clauses.

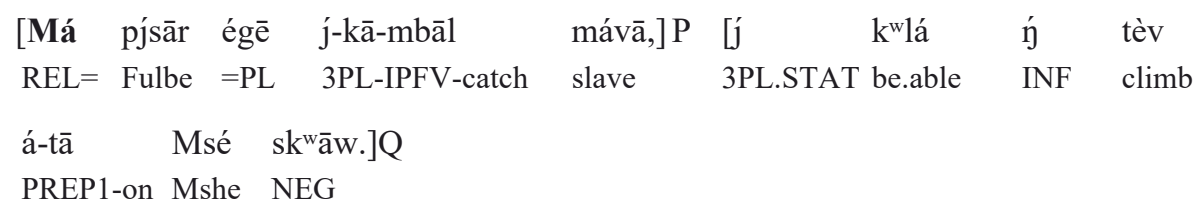

'When the Fulbe were capturing slaves, they were not able to climb up onto the mountain Mshe.'

However, all the examples of temporal clauses marked with the relative marker in natural texts refer to real and specific events. If the event is habitual or generic, the protasis is marked with the possible conditional marker màdā and can be translated 'when' in certain contexts (see example (7) above). Example (22) below comes from a procedural text which describes what typically happens during the traditional festival of Welmbegem. Each new step in the procedure is introduced with a temporal clause marked with màdā. 

(22) Lẃmà Màfàw j-nkràt mávāw. Á dwzé āntā, market Mofou 3PL.SBJ-simmer beer PREP1 after DEF.DET
'On Tuesday (Mofou market day), they simmer the beer. Afterwards, when the beer has finished simmering, in the evening, they pour it into (pots) so that it ferments all night.'

The conditional marker màda can also be interpreted as a temporal marker for certain predictive conditionals as in example ( $3 b)$ above.

\section{Functions of Buwal Conditional Constructions}

In Buwal, as in many languages, the protasis of a conditional construction typically provides a background or framework for the situation expressed by the apodosis. Specifically the protasis introduces a situation in which the apodosis applies, as in example (23) below. In this case the addressee is to call the speaker only if it (for example, the food) is ready.

$\begin{array}{lllll}{[\text { Màdā }} & \text { lá6 } & \text { tsá, }] P & {\left[\mathrm{X}^{\mathrm{w}} \overline{\mathrm{a}}-\mathrm{dàf}-\bar{e} k \bar{e} j\right.} & \text { mā }] \mathrm{Q} \\ \text { if } & \text { ready } & \text { TOP } & \text { 2SG.SBJ-reach.out-1SG.IOBJ } & \text { mouth }\end{array}$

'If it is ready, you (should) call me.'

This framing function is reflected by the common structure of conditionals in Buwal where the protasis precedes the apodosis. The sentence initial position is normal for various types of background or given information. Such information is frequently followed by a topic marker. As mentioned above, the basic function of this marker is to separate information of unequal importance within a sentence. It could be said that the information which precedes the topic marker is backgrounded with respect to what follows. As was observed above in Section 1.1, the protasis of a conditional construction in Buwal frequently ends with a topic marker.

This framing function of conditionals has also been observed for other Chadic languages. Hollingsworth (2004: 46) and Hoskinson (1983: 129) speak of conditionals being 'topicalised' in Mofu-Gudur and Gude respectively. For Lele and Hdi, Frajzyngier mentions the protasis being coded as background with regards to the apodosis (2001: $424 \&$ 2002: 496).

On the rare occasions when the protasis follows the apodosis, it functions as an afterthought providing clarification or a qualification. The sentence in example (24) below has two protasis and two apodosis clauses. The first protasis precedes the apodosis, while the second follows it. This second protasis (underlined in the free translation) qualifies the condition given in the first protasis. 
(24)

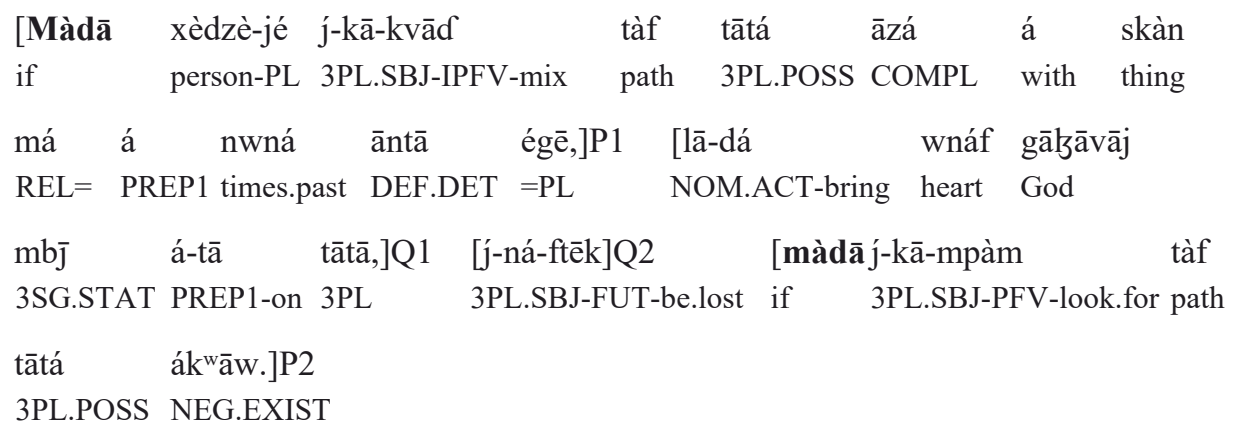

'If people mix their path (way) with things of the old days, the anger of God is on them, they will be lost if they do not look for their path.'

The vast majority of non-elicited examples of conditional constructions occurring in the corpus are found in non-narrative type texts such as explanatory, procedural or hortative. Most of these are what might be called argumentational conditionals in which the protasis is assumed to be true for the sake of argument and whether it is factual or hypothetical is not important (25).

\begin{tabular}{|c|c|c|c|c|}
\hline & $x^{w} \bar{a}-k a ́-d \bar{a}$ & dâlā & lā & dámāw \\
\hline if & 2SG.SBJ-PFV-bring & someone & PREP2 field & 2SG.POSS PREP1 bush \\
\hline & {$\left[\mathrm{x}^{\mathrm{w}} \overline{\mathrm{a}}-\mathrm{ntàr}\right.$} & & dālā.]Q & \\
\hline & 2SG.SBJ- & ay-3SG.IOB & money & \\
\hline
\end{tabular}

'If you have brought someone into your field in the bush to cultivate, you pay him money.'

In another type of conditional, the apodosis evaluates the action described in the protasis (26).

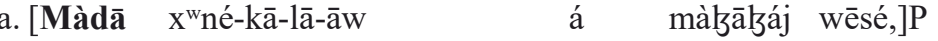
if 2PL.SBJ-IPFV-do-3SG.DOBJ PREP1 speed DEM.DIST
[pá j́ ndràm]Q
at.a.level PREP2 pleasing
'If you do it faster, it is better.'
b. [Màdā sā-ná-ndā tsá, $] \mathrm{P} \quad[$ kádàk $] \mathrm{Q}$
if $\quad 1$ SG.SBJ-FUT-go TOP good
'If I will go, it is good.'

Examples were also found of a type of non-declarative conditional where the protasis describes the act of examining or analyzing a situation in order to reach the conclusion found in the apodosis (27). 
(27)
a. [Màdā xèdzè-dèn-zā $\quad$ tsá,]P [mā $\quad$ āntā $\quad \bar{a}$-ná-ndā $\quad$ vāw?]Q if 1INCL-SBJ-think-TRANS TOP idea DEF.DET 3SG.SBJ-FUT-go Q
'If we think about it, will the idea work?'

\begin{tabular}{|c|c|c|c|}
\hline [màdāánā & sā-sār-zā & tsá,]P [évēlè & ygłèn \\
\hline if like & 1SG.SBJ-look.at-TRANS & TOP although & peanuts \\
\hline $\begin{array}{l}\text { xèdzé-kā-grē } \\
\text { 1INCL.SBJ-IPFV-see }\end{array}$ & $\begin{array}{l}\text { ákā, mbà } \\
\text { EXIST child }\end{array}$ & $\begin{array}{l}\text { á } \quad \text { skā } \\
\text { PREP1 } \\
\text { underneath }\end{array}$ & $\begin{array}{l}\text { tsá, } \\
\text { TOP }\end{array}$ \\
\hline
\end{tabular}

'If for example I look at it, although for peanuts, we see there are leaves, the seeds underneath are gone.'

\section{Conclusion}

A number of interesting observations can be made about conditional constructions in Buwal. Firstly, unlike many Chadic languages, Buwal does not make a formal distinction between reality and unreality type conditionals apart from counterfactual. Furthermore, variations in tense/aspect marking in the protasis and apodosis arise from semantic rather than grammatical restrictions. It could be said therefore, that the interpretation of the meaning of conditional constructions in Buwal is dependent largely on the context rather than on formal cues.

Secondly, the isomorphy of conditional markers with temporal markers has often been observed for Chadic languages. In Buwal it was seen that the possible conditional marker can function as a temporal marker but only for generic/habitual or certain predictive situations. This may indicate that this marker may have had its source in some kind of irrealis marker. It would be worth investigating further, the restrictions on the use of this marker in marking temporal clauses.

Conditionals in Buwal were found to have a number of different pragmatic functions. However, in general the protasis provides a background or framework for the situation found in the apodosis. The fact that the protasis normally precedes the apodosis and is frequently followed by a topic marker supports this idea, as this is the normal position for given or background information in Buwal. Further research needs to be done into the discourse functions of conditional constructions for different genres of discourse. 
Abbreviations Used

$\begin{array}{llll}1 & \text { First person } & \text { IND } & \text { Indefinite } \\ 2 & \text { Second person } & \text { INF } & \text { Infinitive } \\ 3 & \text { Third person } & \text { IOBJ } & \text { Indirect object } \\ \text { ACT } & \text { Action } & \text { IPFV } & \text { Imperfective } \\ \text { ADD } & \text { Additive } & \text { JUS } & \text { Jussive } \\ \text { ANT } & \text { Anticipation } & \text { MED } & \text { Medial } \\ \text { ASS } & \text { Associative } & \text { NEG } & \text { Negative } \\ \text { BEN } & \text { Autobenefactive } & \text { NOM } & \text { Nominalization } \\ \text { COMPL } & \text { Completive } & \text { P } & \text { Protasis } \\ \text { CONT } & \text { Contrastive } & \text { PFV } & \text { Perfective } \\ \text { COP } & \text { Copula } & \text { PL } & \text { Plural } \\ \text { DEF } & \text { Definite } & \text { POSS } & \text { Possessive } \\ \text { DEM } & \text { Demonstrative } & \text { PREP } & \text { Preposition } \\ \text { DET } & \text { Determiner } & \text { PROX } & \text { Proximal } \\ \text { DIST } & \text { Distal } & \text { Q } & \text { Apodosis } \\ \text { DOBJ } & \text { Direct object } & \text { REL } & \text { Relativizer } \\ \text { DU } & \text { Dual } & \text { STAT } & \text { Stative } \\ \text { EXCL } & \text { Exclusive } & \text { SBJ } & \text { Subject } \\ \text { EXIST } & \text { Existential } & \text { SG } & \text { Singular } \\ \text { FUT } & \text { Future } & \text { TOP } & \text { Topic } \\ \text { GEN } & \text { Genitive } & \text { TRANS } & \text { Transitivity } \\ \text { INCL } & \text { Inclusive } & \text { VNT } & \text { Ventive }\end{array}$

\section{References}

Dixon, R. M. W. 2009. The semantics of clause linking in typological perspective. In: R. M. W. Dixon \& Alexandra Y. Aikhenvald (eds.) The semantics of clause linking - A cross-linguistic typology. Oxford: Oxford University Press, 1-95.

Frajzyngier, Zygmunt. 1996. Grammaticalization of the complex sentence - a case study in Chadic. Amsterdam: John Benjamins Publishing Co.

Frajzyngier, Zygmunt. 2001. A grammar of Lele. Stanford: CSLI Publications.

Frajzyngier, Zygmunt. 2002. A grammar of Hdi. Berlin: Mouton de Gruyter.

Frajzyngier, Zygmunt. 2008. A grammar of Gidar. Frankfurt: Peter Lang.

Hellwig, Birgit. 2011. A grammar of Goemai. Berlin and New York: Mouton de Gruyter.

Hoffman, Carl. 1963. A grammar of the Margi language. London: Oxford University Press.

Hollingsworth, Kenneth R. 2004. A survey of clause types in Mofu-Gudur. Yaounde: SIL Cameroon.

Hoskinson, James T. 1983. A grammar and dictionary of the Gude language. Columbus : Ohio State University, PhD. dissertation.

Lewis, M. Paul, Gary F. Simons, and Charles D. Fennig (eds.). 2014. Ethnologue: Languages of the World, Seventeenth edition. Dallas, Texas: SIL International. Online version: http://www.ethnologue.com. 
Lovestrand, Joseph. 2012. The linguistic structure of Baraïn (Chadic). Dallas : Graduate Institute of Applied Linguistics, MA. dissertation.

Newman, Paul. 1974. The Kanakuru language. Univeristy of Leeds: Institute of Modern English Language Studies in association with the West African Linguistic Society.

Noye, Dominique. 1974. Cours de Foulfouldé - Dialecte Peul du Diamaré Nord-Cameroun. Paris: Librarie Orientaliste Paul Geuthner.

Schuh, Russell G. 1972. Aspects of Ngizim Syntax. Los Angeles: University of California, PhD dissertation.

Thompson, Sandra A., Robert E. Longacre \& Shin Ja J. Hwang. 2007. Adverbial clauses. In: Timothy Shopen (ed.) Language typology and syntactic description, vol.2: Complex constructions ( $2^{\text {nd }}$ edition). Cambridge: Cambridge University Press, 237-300.

Taylor, John R. 1997. Conditionals and polarity. In: A. Athanasaidu \& R. Dirvin (eds.) On conditionals again. Amsterdam: John Benjamins, 289-306.

Viljoen, Melanie H. 2013. A grammatical description of the Buwal language. Melbourne: La Trobe University, PhD. dissertation.

Wolff, Ekkehard. 1983. A grammar of the Lamang language. Glückstadt: Verlag J.J. Augustin $\mathrm{GmbH}$.

Melanie Viljoen

melanie_viljoen@sil.org
Submitted: 11August 2015

Accepted: 10 November 2015

Revisions: 23 December 2015 